Portland State University

PDXScholar

Fall 2020

\title{
"I'm Absolutely Ordinary": Bella and Her Perception of Gender within Twilight
}

Jaid M. Eichmiller

Portland State University

Follow this and additional works at: https://pdxscholar.library.pdx.edu/honorstheses

Part of the Children's and Young Adult Literature Commons, and the Feminist, Gender, and Sexuality Studies Commons

Let us know how access to this document benefits you.

\section{Recommended Citation}

Eichmiller, Jaid M., "'I'm Absolutely Ordinary": Bella and Her Perception of Gender within Twilight" (2020). University Honors Theses. Paper 955.

https://doi.org/10.15760/honors.978

This Thesis is brought to you for free and open access. It has been accepted for inclusion in University Honors Theses by an authorized administrator of PDXScholar. Please contact us if we can make this document more accessible: pdxscholar@pdx.edu. 
"I'm absolutely ordinary": Bella and Her Perception of Gender within Twilight

\author{
By Jaid Eichmiller
}

An undergraduate thesis submitted for the partial fulfilments of the requirements for the degree of

Bachelor of Arts

in

\title{
University Honors
}

and

\section{English}

\author{
Thesis Advisor \\ Brenda Glascott, PhD, College Director
}

Portland State University 
Twilight, as a novel, is a phenomenon. With over 100 million copies sold and the popularity of the movie launching a platform for more novels, movies, and merchandise, it has created a culture within itself. The love triangle between the three main characters, with ordinary Bella at the center, has allowed teenage readers to imagine themselves as the relatable Bella, being torn between two hot supernatural creatures. But, Twilight is not merely a piece of young adult fiction, but instead has created a larger cultural impact regarding vampires, teen romance, and gender. As the reader is immersed into Bella's point of view, they are encouraged to view the world as she does. Because of her role as both main character and narrator, her own thoughts and beliefs are forefronted for the reader, allowing the reader to align themselves with her from the beginning.

Bella's voice as the narrator is integral to the novel. This first person novel gives readers an immersive experience in her perceptions, particularly about how she sees humans and vampires, gender, beauty, and virtue. In my thesis, I explore what a close analysis of Bella's perceptions and judgements - as evidenced through her voice - reveals about the larger gender politics (including the perception of femininity) in the novel. What do Bella's perceptions and judgements about herself and others tell us about how she sees gender roles and femininity?

\section{Summary of Twilight}

The novel centers on the protagonist, Bella Swan, who is an Arizona transplant in Forks, Washington living with her father, Charlie. She receives a lot of attention being the "new kid," but she appears to only care about the mysterious Cullen family, specifically Edward. Their relationship is rocky, fraught with passion and talk of danger, until Edward reveals that he is a vampire. Despite this, Bella is still very much enamored with him, and famously says she is 
"unconditionally and irrevocably in love with him". This relationship spirals out of control in face of enemy vampires who want to kill Bella. The climax is a fight back in Bella's hometown of Phoenix, which ends with her hospitalized. Through all of this, she maintains her relationship with Edward and we are left with the assumption that Edward will eventually turn Bella into a vampire.

There is obviously a lot more to the story, as the novel is the first in a series of four novels, with an added novella and film franchise. Despite the complications of the rest of the series, and the eventual wedding and childbirth, I am focusing on the first novel. The novel, told in first person narration by Bella, is essential to the beginning of the story that has captured so many readers' imaginations. Twilight details first impressions, judgements of characters before becoming wrapped up in Edward, and the initial thoughts of what vampirism means to Bella as a character. Her own thoughts in these moments, and the messages that they are telling to the reader, are essential when discussing the novel and the series. My focus on the first novel will work to reveal how feminist ideals are handled; a close reading on Bella's judgements, perceptions, and values will reveal more about how Stephanie Meyer handles the concepts of feminism through this specific voice. Much of the discourse about Twilight surrounds this question of feminism, and this close reading will work to answer the questions about Bella's thoughts and feminism present in the first novel.

Scholarly Conversation regarding Twilight and Feminism

Scholars argue about whether Twilight is or isn't a feminist novel. Much of the discourse falls into two arguments. The first is that the novel and series is inherently feminist due to Bella's strong will, her ability to choose, and the ways in which she empowers herself to get what she 
wants. The second argument claims the novel is anti-feminist for numerous reasons, including upholding traditional feminine ideals and supporting patriarchal power structures. The focus is either on the larger saga and the ways in which vampirism ultimately is feminist (Ryan), or that vampirism is increasing maternal stereotypes and playing into the patriarchy (Gerhards). Central to any of these arguments is what feminism and how it relates to the novel.

The definition of feminism is complicated, and frequently different from scholar to scholar. The formal definition from the Merriam-Webster dictionary states: "the theory of the political, economic, and social equality of the sexes." There is also the concept of "choice" feminism, which is defined as: "the idea that feminism should simply give women choices and not pass judgement on what they choose" (Snyder-Hall). For the entirety of this essay, I will define feminism more closely to that of Rebecca Walker, the acclaimed founder of Third Wave feminism. In her text titled "Becoming the Third Wave," Walker says, "To be a feminist is to integrate an ideology of equality and female empowerment into the very fiber of [my] life" (Walker). Rather than focus on the concept of "choice," as many feminist definitions feel a need to emphasize, I am choosing to focus on the ideals of equality and empowerment throughout aspects of life. What I have found is that even through choice, the internalization of patriarchal values leads to the upholding of traditional gender roles that subjugate and oppress women. By emphasizing empowerment along with equality, this concept of feminism is more distinct from a more lenient definition and construction that holds looser, less specific values.

The larger scholarly conversation surrounding Twilight does not focus on a single novel in the series, nor the first novel. Often, the claims about the series focus on all of the novels, and some even incorporate the film franchise into the discussion. And, continually more frequently, the discussion includes the other characters within the series as necessary components within the 
discussion of issues within the series as a whole. The larger discourse that I am focusing on is the discussion of Twilight as a feminist novel. However, within the scholarship about the original novel and the saga, there is a distinct lack of discussion of Bella's voice and opinions as the driving factor in these feminist, or antifeminist, claims. Bella's first person narration is distinctly not present within the larger discussion, with a focus more on general events and actions.

Interestingly enough, Stephenie Meyer calls herself a feminist in an interview with the Guardian. She states that she "loves women" and loves working in a "female world." She also states her dislike for politics and that she does not intend to include any messaging within her novels (Cochrane 2013). Despite this assertion, the question of feminism within the novel, and the larger messaging it puts across, are heavily discussed.

The argument for feminism within the novel stems from this concept of vampirism as an equalizer that ultimately offers the strong female characters that are vampires as a sort of “enlightenment" to feminism. While this argument also acknowledges the ways in which Bella's classmates and other female characters are feminist in their actions, this version of the reading frequently focuses on the ways in which vampire women are the epitome of feminism within the series as a whole. Mary Ryan, a renowned literature and feminist scholar, discusses the ways that female vampires function as equals within the novel and are able to take on any role or skill. Ryan says, "[it] may also be suggested that in which everyone, men and women, are valued for who they are rather than for their gender" (Ryan 144). Within the series, vampires all have equal strength, and Ryan even cites the continual portrayal of the female vampires as more vicious as a representation of power and strength for women within the series. This reading specifically focuses on the latter half of the series, where Bella becomes a vampire. This is important to note, for the consideration that the novel only becomes feminist or holds a feminist perspective once 
Bella becomes a vampire, according to Ryan. Despite this, Ryan still pulls on many aspects of the novel, including Bella's pervasiveness and her strength throughout as a way of legitimizing Bella's role as a feminist.

Another argument for feminism within the series is the many options that Bella has and her ability to choose her own destiny. On her own website, Meyer addresses the question of Bella as an anti-feminist character by saying, "the foundation of feminism is this: being able to choose" (Meyer 2010). Other scholars, such as Merinne Whitton and Natalie Wilson, cite Bella's choice to become a vampire as an act of feminism; she has many choices and decisions to make throughout the novel, and her choice of her bodily autonomy is important within the larger context of the series. Her decisions- to marry, to have sex, to have a child-all work towards this support that Bella is enacting feminist ideals by choosing each of these options within her life.

A contradictory character within the novel is Rosalie, Edward's adoptive sister and vampire. Ryan holds up Rosalie's character as one of the purest examples of feminism due to her strength both as a feminine character and through masculine hobbies, like fast cars. Lauren Rocha, in her work regarding the gender roles within the series, argues against the feminist reading by digging deeper into the desires of the vampires themselves. In reference to Rosalie's description as being beautiful and smart, she says, "Meyer ultimately recedes into a conservative view of women's roles in Rosalie's desire for the traditional female roles of wife and mother" (Rocha 273). Rocha pointedly notes the ways in which Rosalie's character as a vampire and feminist are reversed by the desire to be a housewife with children. While Ryan's argument focuses on the ways in which Rosalie is treated equal is feminist, Rocha dismantles this concept by noting the ways in which the series distinctly corners Rosalie into a specific housewife role. Rocha, in her examination of gender roles, interprets the novel as an anti-feminist reading 
through the ways in which traditional female housewife and mother roles are valued within the novel. She notes themes of passivity, continued control of body by male counterparts, and the single-minded desires of femininity that a majority of the characters display. These qualities are clearly evident to all, and as film critic Lucy Mangan aptly puts, "Bella all but disappears as a character" in the face of Edward, her main male counterpart (Mangan). Bella's disappearance into her own narrative is heavily discussed within the larger feminist discourse.

Another part of the argument surrounding feminism includes a heavy discussion of religion, frequently noting the importance of Christian themes throughout the series and Meyer's own claim of Mormonism. In particular, Lind sey Issow Averill discusses the connection between the text and the story of Adam and Eve in her work titled, "Un-biting the Apple and Killing the Womb: Genesis, Gender, and Gynocide" (Parke and Wilson). By comparing the characters and the overt Christian themes to the story of Genesis, Averill argues that Bella's actions and the result of the novel are inherently anti-feminist. This connection between religion and the text is frequent, but this particular lens is essential to the overall arguments about the series. She states that due to the novel revolving around Edward, it mirrors the tale of Genesis and Eve living within a male-centric worldview. Beyond that, she argues that the stripping of reproductive abilities in the vampirification process limits the female form and strips female vampires of agency. Because of this line of thought, Averill argues that Bella's eventual turning into a vampire is an act of anti-feminism. This argument - that the work as a whole is an anti-feminist work - is a commonly held belief within the larger scholarly conversation surrounding feminism and the novel.

Less frequent are scholars that fall in the middle, with arguments not necessarily supporting or condemning the book's perceived values. Rhonda Nicol, in her comparison of 
Bella to Buffy the Vampire Slayer, argues that the discussion of sex throughout the series can be interpreted in many different ways, not all necessarily feminist or anti-feminist (Nichol). Another scholar, Christine Jarvis, claims that Bella's actions do not support either side because of her “intentional emotional blackmail” throughout the series. (Jarvis). Jarvis' argument is extremely valid when it comes to the larger discussion of feminism within the novel, as she even goes as far to title her work "The Twilight of Feminism?" Her overall argument does not necessarily make a claim in the more decisive ways that other scholars have. She focuses more on the text and less on the feminist claims that have come before. These arguments, like many of those in the scholarly community, focus on scenes from all four novels, with supporting quotes. These claims also ignore the gaps that occur when focusing too heavily on Bella's actions later in the series. Many often cite Twilight only within the last 50 pages, where the climax of the novel occurs, focusing on aspects of vampirism and violence. The discourse community is effectively ignoring nearly 400 pages of Bella's thoughts and perceptions, the same thoughts and perceptions that cause first time readers to want to continue to read more.

Even those texts that focus more distinctly on Bella as a character, rather than other vampires and her interpersonal relationships, focus distinctly on actions and events rather than the thoughts and feelings that Bella has. As the first person narrator, her viewpoint is deeply embedded into the character of the novel, yet her voice is often ignored in face of examining other anti-feminist qualities within the novel or series. While arguments surrounding class and gender are important within the larger context of the series ${ }^{1}$, the overall sentiment behind much of the discussion falls into the events and qualities that characters have that are separate from Bella as a character and narrator. The discussion of gender is important to the novel as a whole, but when placed out of the context of Bella's own thoughts and perceptions, the larger argument 
ends up straying towards the "objective" events and facts within the novel. What I find needs discussion is the way that Bella discusses these individual qualities, and the words that are used to describe her own perceptions of the events around her. By doing a close reading of Bella's own words and perceptions, the larger thematic issues of gender and feminism will become illuminated through the narrative story that Bella tells.

Both the novel itself and Bella as a character are separate feminist identities, but within the function of the novel as a whole, they are inevitably the same. Because of the first person narration that occupies the novel and forefronts Bella as a character, Bella's personal feminist ideals inherently become the novel's feminist ideals. While the novel has small moments that can be analyzed as feminist by scholars, those specific moments function outside of Bella's own narration, and frequently outside of her as a character. I will focus specifically on the novel and Bella as one feminist identity.

\section{Bella's Perceptions of Self}

What is inevitably important within the composition of a novel is the voice in which it is told. Because Twilight is told through first person narrative, the voice of Bella is clear within every literary choice made throughout the novel. It is her thoughts, expressions, feelings, and interpretations of everything that is going on around her within these scenes. This internal monologue that we get from Bella is highly important when thinking about the relationship of character to thematic choices, like whether or not the novel is inherently a feminist work. The ways in which Bella talks about herself, others, and societal expectations is highly important in deciphering whether or not her voice, and thusly the novel, is promoting a feminist viewpoint. Bella's narration throughout the novel moves through various judgements and opinions of both 
others and herself, which is what I am analyzing here. She has a strong viewpoint about a lot of things, but in particular she is very aware of how she views herself.

Those reasons, and others, are why Bella's voice is ultimately regarded as reliable. This is supported by her confidence, her maturity that she displays early on, and the continued story without contradiction or interruption. None of the information that she specifically shares is challenged outside of Edward, who seeks to manipulate her into staying away from him and frequently enacts levels of psychological manipulation, or gaslighting. The reader is arguably taught to acknowledge Bella's voice as trustworthy because of her practicality as a human. Early on we see direct evidence of her decision-skills and ability to sacrifice for others (Meyer 1), and these specific actions set up a narrative environment that gives no other option but to trust the information she is sharing.

Bella's perception of self is complex throughout the novel. She views herself as both competent and capable, while also degrading herself based on specific characteristics. Her own perception of her maturity is established early on in comparison to her mother. As she is leaving Phoenix, she thinks, "How could I leave my loving, erratic, hare-brained mother to fend for herself?" (Meyer 4). This quote reveals a lot about Bella's perceptions of both herself, her mother, and their relationship. The qualities that she uses to describe her mother vary, from both positive, with the term "loving," to negative, with the term "erratic." The connotation of calling her mother "erratic" and "hare-brained" paints a very specific picture of how Bella views her mother and her parenting style. To Bella, her own description of her mother is one of uncontrollability, even as she uses "loving" to counterbalance this. The rest of the thought is then summarized with her saying "fend for herself," which adds a different layer of judgements onto Bella's thoughts. This phrase says a lot about both Bella and how her relationship works with her 
mother. She is inherently claiming that her mother cannot fend for herself, which implies that Bella's existence up until this point has been to help and assist her mother. Her words imply that their relationship is far from the socio-normal relationship, with the mother taking care of the child. Bella implies that she, as the child in the relationship, has maturity and takes care of her mother. This thought that Bella has is very important within the larger terms of how she views herself and her role as a female throughout the novel; her perceptions of what qualities are important within a woman start with her maturity and ability to take care of her mother.

In turn, Bella constantly degrades herself and her value as a person through her own self descriptors. She frequently uses "clumsy" and "ordinary" as self descriptors, both in her own narration and when she speaks. In particular, when describing herself to Edward, she says, “'I'm absolutely ordinary... [and] so clumsy I'm almost disabled"' (Meyer 210). Her frequent use of these words, and her frequent comparison of herself as ordinary to the "extraord inary" Edward, is a way she degrades her own value. Instead of focusing on the values of herself that are positive, there is a consistent insistence through her narration that her life has very little value. Here, she is claiming that her clumsiness is affecting her daily life by claiming she's "almost disabled." This implies a lack of physical ability to perform and move through life with ease, and yet Bella is perfectly capable of doing quite a lot. Within her own descriptions of clumsiness, the novel rarely backs up this case; her physical actions are frequently average and would not be considered "clumsy" by any standard. This narration and thought process that leads Bella to insist that she is very little, or merely ordinary, persists throughout the novel. Her own self description is evidence for the fact that her concept of gender and self-criticism is internalized (Schacar, Parke \& Wilson). 
Her own description of herself as clumsy also works to desexualize her as a character. The traditional roles that she takes on throughout the novel of mother to her own parents align her with a more traditional feminine role, which as a mother begins with sex. Despite the linkage between herself and her motherhood role, she contrasts this with her own shortcomings. Her own assignation of clumsiness and aligning herself with the ordinary give her child like qualities. By contrasting her two dominant roles - caretaker and child — she is effectively placing herself between the two. She offsets her own perceived shortcomings with her "good" qualities that she works hard to maintain, such as the housekeeping and caretaking. Through her own voice, she contrasts her lack of control as a klutz with her aptitude towards adult-like, traditionally female chores. She is both a child and an adult, according to her own perceptions of self.

This duality is challenging for a reader due to her confidence in herself and her abilities to be adult-like, but also contradicting her own word s by consistently calling herself clumsy and degrading her own personhood. Throughout the novel, these concepts are often contrasted in ways that contradict each other. In one scene, Bella is making dinner for herself and her father, continuing the caretaking practices she clearly had in Phoenix with her mother. Only moments later, her thoughts are consumed with the fact that she is not "interesting" (Meyer 79). Bella's narration contrasts her own concept of self, leaving the reader moving back and forth between assigning value and devaluing her based on how she presents herself. Her presentation of self is frequently negative, as seen with the specific use of words that she describes herself with. Scholar Tammy Dietz aptly says, "Bella, a character made to appear romantic and desirable, is a model of ineptitude" (Dietz 103). This analysis of Bella's character is extremely accurate to Bella's own depiction of herself. Her entire personality is contradictions of capability in 
traditional female gender roles and her own statements of boring and clumsy incapability as a person.

What is also interesting about how she assigns value and the ways in which she describes herself are the times she allows herself to talk positively about what she is doing. Through her narration, we can glean moments of positivity about herself in regards to specific tasks and qualities. For Bella, with both parental figures, the positivity she has with their relationships comes from taking care of them. She places value in her ability to take care of them. We see that early on when she says goodbye to her mother (Meyer 4), and a few more times when she interacts with her father. Almost every scene with her father revolves around dinner; she is frequently making dinner or preparing food for dinner while Charlie is getting home from work. She views her ability to do this positively, saying, "It was fun to watch as he slowly began trusting me in the kitchen" (Meyer 80). We see her thoughts in this moment as she takes pride in her ability to cook. She pointedly uses the word "fun," which implies that she is gaining enjoyment from her father eating her cooking. This exchange of trust, and the idea that her father can trust her cooking, places a positive value on her qualities as a chef and a homemaker. Her positive qualities are frequently assigned to cooking and cleaning, and she prides herself on her ability to be "mature."

Her own assignation of positive qualities towards traditionally female, homemaking qualities is subtle, but important within Bella's first person narration. By assigning positive qualities to traditional homemaking and home care tasks, her own judgements about important qualities in a woman are revealed. Early in the novel she even states that she enjoys grocery shopping because "it felt normal" (Meyer 32). This is essential within our first perceptions of Bella as the main character, and as the narrator. It is heavily introduced early on that she is 
matronly and takes on many of the traditional homemaking roles that are assigned to women. Bella's own perceptions of them as "normal" and enjoyable send a clear message to the reader that these specific activities are what the average teenage girl should like and aspire to be. Bella's own likes about herself reaffirm traditionally gendered roles, such as those of wife and mother.

Her own assessment of normality and positive qualities is evident through her narration due to her word choice and her specification of language, but it is often clouded or overshadowed by other things that she deems important. Her assignation of positivity towards these homemaking qualities is often hidden underneath her insistence that she is not feminine and the pride she takes in that. She frequently distances herself from other girls and often has side comments about herself that separate her from the others. When she goes shopping with other girls, she says, "[I] switched my scruffy wallet from my school bag to a purse I rarely used" (Meyer 151). This use of language is important within her perceptions of herself and her femininity. By using the word "scruffy" to describe her wallet, she is removing herself from any concept of glamour, with the word invoking a specific imagery of old or worn down. On top of that, she says "a purse I rarely used," which points out that she specifically never uses that purse, or any purse. This denial of feminine qualities in this moment is particularly interesting in contrast to the highlighting of traditional homemaking qualities that she has taken pride in. The duality of Bella appears conflicting as she is both a traditional woman, and not your "average" girl.

On top of the denouncing of femininity that works within this scene, this moment, among others, shows the ways in which Bella over critiques aspects of her life. These overt critiques function as a break between the seriousness of her own positive self worth and the reader's view 
of Bella as a character. Bella is assertive in knowing herself and her positive qualities, but she also offers these opposite aspects, as if to encourage the reader to view her negative qualities as quirks of her character. By assigning herself this duality - the capable adult and the relatable, childlike klutz - Bella's criticisms of traditionally feminine things, and her own criticisms of herself, become quirks. She creates a world scape in which her own criticisms are what makes her a relatable character.

The disdain that Bella expresses about femininity, and the critiques that she uses to ensure that the disdain is masked in humor and relatability, come to a head in the epilogue. She describes a day of being pampered by Alice, which includes being a "helpless victim" of makeup and wearing a "ridiculous blue dress" (Meyer 482). More importantly, Bella says, "I'm not coming over anymore if Alice is going to play Guinea Pig Barbie"” (Meyer 482). The specific word choice that Bella uses to discuss traditionally feminine aspects are both her own personal critiques and framed as almost humorous retorts of relatability. By calling herself "helpless," Bella is specifically placing herself out of control of the situation; she is blaming the entirety of it on Alice, thus placing the responsibility of upholding traditional gender roles on Alice rather than taking personal ownership. She further distances herself from the aspects of femininity by using the phrase "Guinea Pig Barbie." By offering a slightly outlandish image and implying that she is both a test subject and a plastic doll, Bella is distancing herself from the traditional feminine qualities of a Barbie doll. The image she paints is meant to give the reader a negative image; her own discussion of femininity within the epilogue shows a distinct disdain and Bella works to demean aspects of femininity.

This epilogue functions as a conclusion to the romantic story and complex fight at the end of the novel, but it also functions as a reflection of Bella throughout the story. By including 
this specific set of scenes, it allows Bella another scene to display her personality and the duality that rules it. She clearly displays the disdain for the feminine, which is framed as relatable, but she also displays her childlike qualities through a near temper tantrum regarding going at all. Within her own narration, she admits her childlike behavior by saying, "The angry tears rolled over my cheeks" and also saying that she "pouted" about it (Meyer 484-5). Within her duality of character, even at the end of the novel, she continually plays up both the anti-feminine and the childlike qualities that she expresses. Angry crying about going to prom is viewed as ridiculous by Edward in this context, and her own verbiage about her actions supports this specific notion. She even goes as far to say, “I feel like I'm 5 years old”" (Meyer 488). This aligns her more directly with her own child-like side, which she associates more directly with clumsiness in the first half of the novel. She is aware of her own immaturity in face of others, and in this moment acknowledges the fact that she portrays herself as younger.

Despite all of this, she also shows the other half of her own duality through her endless desire to be with Edward forever. She even pointedly says, "'Mostly I dream about being with you forever'” (Meyer 498). While she does not explicitly say she wants to become a wife or mother, the concept of "forever" is culturally tied to heterosexual marriage. This reaffirms her position as the wife and mother; despite all of the child like behaviors and disdain for traditional femininity, she has a longing desire for the traditional female gender roles of wife, and presumably, mother. By expressing her qualities through such extremities, she is both highlighting herself as an example of each half of her duality while presenting her own identity as a middle ground.

Bella's Perceptions of Others 
The larger sentiment of Bella's judgements and her worldview extend beyond how she describes herself. Her perceptions of gender and femininity in particular are evident within her relationships with her classmates. In the beginning of the novel, much of her judgements and perceptions about her peers are established through the narration when she starts school. While she does not make direct statements regarding how much she does or does not like someone, the words that she chooses to use while describing the group of peers she joins as her friends is telling of her own perceptions of them as people. The first non-vampire peer that she describes is a boy named Eric, who had, "skin problems and hair black as an oil slick" (Meyer 16). She also calls him a "chess club type." While these things are not overtly coded as positive or negative, the features that she chooses to describe him with are marked. She first begins by pointing out an obvious imperfection, judging him closely on first his physical appearance. She then makes a judgement decision based off of his appearance by calling him "chess club type." This specific narration is image evoking; for the reader, the interpretation of this character is clear not only through the marked physical attributes but the 'type' that Bella equates him with. Within the first moments of meeting him, his character and personality has been stereotyped based off of the specific description and her own judgement. While she does not say anything negative, within the traditional hierarchical teenage social life and the interpretation of stereotypes, the reader can assume certain qualities that might concur with this description (nerd, geek, unpopular, etc). Her own judgement in this moment colors the way that the reader will see Eric as a character, and with minimal attention to Bella's peer group once she begins a relationship with Edward, these small judgements are frequently the only way that the reader knows the character.

She codes much of the human peers that she interacts with in a negative light. Like with her description of Eric, many of the descriptions of the human males tend to point out their 
flaws, rather than their good qualities. By doing this, her own value of personhood is rooted within attractiveness and inherently "positive" qualities, and the definition of gender begins to be more about what a person is not, rather than what they are. Bella even acknowledges her own judgements about characters when she encounters Jacob for the first time at the beach. She calls him "beautiful," which has been reserved for the vampires up until this point in the novel. At the same time, she also states that he has a "hint of childish roundness" in his face. While this does not contrast with the concept of beauty in this context, his looks are contrasted with both the average boys at her school and the mature perfection of vampires. Her own judgments are acknowledged when she says, "However, my positive opinions of his looks were damaged by the first words out of his mouth" (Meyer 119). By specifically pointing out her own relationship with positive and negative interactions and judgements, we can see how her own narration takes us through the same journey. While she as a character is the one making these assessments of people, we as a reader are taken along and encouraged to think the same way as her through the first person narration. As she acknowled ges her own thought process for assessing Jacob as a person, the readership is confronted with the idea that Bella's narration is not fact based, but rather opinion based.

Mike Newton is the only human boy to escape this negative description. She says that he is "cute" but also says that he has a "baby face". While Mike escapes the directly negative assessment, she immediately uses the term "baby face" to strike him out of dating potential. As with Jacob, by likening him to a child, her own perception of him as a person is clear; she believes that he is physically immature, and by pointing this out, makes it clear what sort of relationship they are bound to have. Her own perceptions of herself are evidently of a mature adult; we can see this through the ways in which she places herself as more mature and 
responsible than her mother and father. Here, she does the same through his physical description. By describing him this way, her own judgement of gender begins to take shape. She is outlining aspects and qualities of him that are not necessarily bad, but do not fit with the typical heteronormative male stereotype. The qualities that she asserts him with do not follow the typical male romantic partner depicted in young adult literature, and by pointing them out, she is also showing how she does not value these qualities. At one point she says, "I imagined him with a wagging tail" (Meyer 51). Through this statement that he is inherently puppy-like, it allows the reader to view him as undesirable, or nothing more than a cheerful dog. Categorically, she is placing him as outside of the desirable male gender type. By critiquing his masculinity through infantilizing him, she is effectively perceiving him as an immature man, and not fulfilling the attractive, tough, masculine stereotype.

In direct contrast to how she describes these particular boys is the ways in which she describes Edward. The word "perfect" is used to describe Edward 23 times throughout the novel. Whether it was his perfect face, or how perfect his articulation and manners are, Bella's own perception of Edward can be summed up by the word "perfect." That word alone has an immensely more positive connotation than the other descriptive words she uses to describe the human males at her school. The things that she notes are "perfect" about his physical appearance include, but are not limited to: his face, his chest, his teeth, and the general makeup of his body. Her own perceptions of the male gender can clearly be seen through her descriptions of Edward in contrast with other males, and particularly how she values his qualities. Her overwhelmingly positive reaction to his physical state makes it evident that he falls into the ideal, or "perfect," depiction of the male gender, and that his physical appearance is heavily valued. Through her 
constant assurance that he embodies perfection, we can then assume that the qualities he has are the qualities that she values in a male body.

This insistence of his perfection becomes problematic in the larger scope of the novel. The extremism of both his role as a vampire, and the qualities that are associated with that, make it impossible for any other male to achieve the same level of perfection. Bella's attraction to him and the distinct marking of him as "perfect" lead her to mark that only the perfect man, or perfect male gendered person, is desirable. She asserts this position through her descriptions of the other vampire males who are Edward's adoptive brothers. In her assessment of their appearances, Bella says, “[T]heir noses, all their features, were straight, perfect, angular" (Meyer 19). In her first interaction with them, she prioritizes their physical appearance and places heavy value on the ways that each of the male vampires look. She uses traditionally positive connoted words, including muscular, to show her own opinion of them as an idealized form of the male gender.

Rather than directly commenting on value through physicality, Bella passes judgement on the female body image and its correlation to personality. As with her male peers, the female peers are frequently described with negative qualities. Even unnamed characters are described with Bella's judgments, as she describes a girl as having "braces and a bad perm" without ever mentioning this peer again. Through this specific micro-interaction with an unnamed classmate, we can see how her own judgements about others are forefronted in an effort to aptly place Bella within both the physical and social hierarchy of Forks High School. By putting others down through negative interactions, the supposedly plain Bella is placing herself above them. She is creating her own judgmental system in which she is allowed to rise to the top for being "unremarkable." 
The peers that become her long term friends are not exempt from this description. Frequently, the females that she becomes friends with have minimal physical descriptions. She often refers to them by name or by the fact that she cannot remember their names. This detail alone is telling to her own perception of femininity; Bella views the female peers that she interacts with as inherently forgettable, which allows the reader to assume the same. It isn't until later in the novel (Meyer 78) that we get a clear description of Lauren and Angela, who are described as "standoffish" and "shy" respectively. While neither word is inherently positive, they are marked when it comes to their descriptions. By marking them with particular stereotypes, Bella's descriptions of them are meant to invoke a specific image from the reader. Later, when Bella calls Lauren "unfriendly," we are distinctly pointed to know that Bella, and we as readers, do not like Lauren. She forefronts her opinion of Lauren and her personality over any physical description, which marks the assessment of female peers as distinctly different. The first person narration and the way that it gives details into Bella's thoughts and perceptions align the reader and Bella, allowing the reader to feel and assume the same things that Bella does. By giving these vague, single word descriptions, the reader is meant to fill in the blanks. This then allows the reader to assume things about the female peers, including the reader's own perceptions of gender stereotypes and femininity.

This is made more apparent when contrasted with the descriptions of the female vampires throughout the novel. Both Rosalie and Alice, whom Bella interacts with the most, have detailed physical descriptions and are described as "perfect." The "perfect" physical description of Rosalie is: "She had a beautiful figure, the kind you saw on the cover of the Sports Illustrated swimsuit issue, the kind that made every girl around her take a hit on her self-esteem just by being in the same room" (Meyer 18). This description paints a very specific image, and by 
associating it with perfection, Bella's own ideals about femininity are evident. She views this specific type of woman as being "perfect," which is inherently a modelesque and immensely beautiful woman. She describes the female vampires much like she does any male counterpart throughout the novel; the physical attributes are the first things that she sees and thus describes. The concepts of the female gender that Bella emphasizes through this description includes a perfect body, as well as beautiful model features. When contrasting this with the other descriptions of female peers in the novel, this more detailed description places Rosalie and the vampiric concept of feminine beauty as inherently better than the average human female peer. By including it within the narration, Bella places value on it in comparison to the descriptions, or lack thereof, of the other female peers.

These cases of Bella's own perceptions of beauty and femininity are characteristic of classic heteronormative beauty stereotypes. The stereotypes of beauty, particularly modelesque beauty as above all else, is evident within the prioritization of the vampiric beauty within the novel. The vampire characters are all distinctly beautiful, and Bella's continual admiration for their "perfection" clouds her own narration. By including a continuous assertion that the vampires are beautiful, Bella is placing beauty and their physical attributes as an essential part of their gender and overall identity.

The larger scope of women within the novel can be categorized into two judgmental categories within Bella's own narration: traditional and nontraditional. Bella's own feelings about these two groupings can be evidently seen within her descriptions of them, and the way that they are eventually characterized throughout the novel. The prime example of this is the difference between Esme, the vampire mother, and Renee, Bella's own mother. While we have already discussed the way that Renee is characterized as "hairbrained" and is shown as being 
incapable, Bella's perceptions of motherhood in the novel directly contrast her own mother. In an interaction with Esme, Bella says, “'You sound like my mom”" (Meyer 368), but this is not necessarily to compare them as similar. This statement follows Esme talking about her deep love and passion for motherhood, even going as far to call the other vampires her "children". Esme even says, “I could never get over my mothering instincts"” (Meyer 368). This quote in particular is important for the overall perceptions of femininity and gender roles within Bella's perceptions of the women in her life. By giving Esme the particular "mothering instincts," Bella associates motherhood with an inherent quality that women are supposed to have. This asserts her own perception of motherhood as a quality that one is born with; those who exist within the novel either are good mothers or are incapable. By asserting this notion, Bella is asserting that gender roles like motherhood are not something that can be taught or learned, which thusly creates the idea that motherhood is an inherent aspect of being a cis-woman.

While Bella directly compares Esme to her mother, the other evidence that Bella provides within the novel contrast them as anything but similar. As Ashley Donelly says in her essay "Denial and Salvation" within Theorizing Twilight, "Renee, who left Charlie in what is described as a heartless, selfish fashion, abandoning her role as wife, is depicted as clearly defective... She does not fit into the female gender role subscribed to by those in a heteronormative, patriarchal system" (187). Bella herself, through her first person narration, depicts her mother in this light. By making her mother an Other, she then provides the example of Esme as the caring and dedicated mother, having picked up an entire vampire clan as her children as soon as she was created. This contrast supports the identity of women and the female gender within the novel and perpetuates the idea that mothering is "instinctual" or inherent. The characteristics that Bella values, both within herself and others, are of kind, beautiful homemakers. Esme is the perfect 
example of all three aspects that Bella places value on in consideration of herself and those around her and truly embodies the concept of "mothering instincts."

Throughout the entire novel, the characteristics that she values surround kindness, beauty and perfection, and a level of homemaking ability. In concerns with femininity and the way that feminism itself operates within the novel, the qualities that Bella values align with a more traditional view of both male and female gender. She overtly values traditionally feminine qualities both in herself and in others; by placing a heavier emphasis on homemaking and beauty, Bella is more directly stating her own investment and value of the traditional woman role as a wife and mother. Within the examples of comparing the two mothers, Bella is comparing nearly direct opposites in their choices as persons. Renee chooses herself consistently; she leaves Charlie for herself, and eventually leaves Bella to pursue her own happiness. In direct contrast is Esme, who is a traditional housewife and mother to the extent that she can be; Esme has tied herself eternally to her husband, and has adopted five "children" of her own, not working in order to be as selfless as possible and as available to others as a wife and mother.

When considering a comparison between the mothers in regard to gender perceptions, it is equally important to examine the characteristics of the fathers represented, both human and vampire. The ways in which Charlie is represented are almost equal and identical to the representation of Renee in many ways. He is equally incompetent at being an adult human as Renee is; Bella says distinctly that, "Charlie couldn't cook much besides fried eggs and bacon" (Meyer 31). Like with her mother, Bella is highlighting the incompetence of her father. By framing him as a distant parent and incapable of taking care of her, Bella's judgements of his character allow her to be viewed as a mature and adult person. Even Charlie is aware of her treatment, because he says, “'You baby me too much” (Meyer 358). This relationship 
perpetuates the narrative that Bella builds throughout the first part of the novel; Bella is a caretaker to all and adopts the role of mother and wife within all of her close relationships.

Her own values that she puts importance and value on within the first part of the novel, as she is describing who she is as a person, she then extrapolates into the relationships she has with others. By valuing and liking traditional gender roles (caretaker, mother, wife), she reaffirms her own place within those set gendered roles. When she enacts this with her own father and mother, she is taking on the role of mother (to her own mother) and wife (to her own father). This is contrasted by the other set of parents that Bella includes, which is the perfect vampire Cullen parents.

Carlisle, as a father, is more heavily described by Bella and talked about compared to Esme, but his characteristics and values are that of a more traditional male role. He is described as the epitome of self control and is extremely forgiving as a father, as Edward describes him. When he treats Bella in the ER, he is described as "concerned" for her (63). This is more than she gives to her own father, who doesn't seem to show any outward signs of concern for her within this particular moment. Besides this moment of concern, he is also described as having authority, particularly when they are handling the rogue vampires who intrude on the baseball game. He is then described as "cool," "level", and having a "voice of authority" (Meyer 372-3). These qualities are frequently what one would associate with a traditional male gender role, such as leader or father. By associating him as the leader of the Cullen clan, and giving him these attributes when he speaks, Bella is asserting him as a good, strong father and leader of their group. She is associating the positive qualities of traditional male roles, allowing him to be seen in a distinctly more positive light than her father. By comparing the two, and the distinct ways in 
which their relations function, we can see how she views the imperfection of her own father in comparison to the perfection of the traditionalist Carlisle.

Her depictions of men within the novel differ greatly depending on their specific role in her life, with her relations with the fathers functioning vastly differently than her relations to her classmates. Despite insisting that she is unfeminine and "clumsy," her status as desirable in the eyes of her peers is communicated to the reader clearly from the start of the novel. As the new girl, her arrival at Forks High is a big deal, with everyone wanting her. She is asked to the spring dance by three different guys in her class, despite the dance being a girl's choice. This fact alone, and the three guys who ask her, prove the fact that she as a character has a level of desirability to her. If she was as undesirable as she claims to be throughout the novel, then she would be ignored like much of the other females she encounters. This is why her relationship with Edward, and their communication about their desires for each other, is integral in how Bella perceives herself and how she inevitably presents herself to the reader.

Bella's relationship with Edward

The one character that insists that she is beyond her "ordinary" appearance is Edward, who heralds her as much as she speaks of him. He frequently talks about her as if she is beyond the average self that she depicts. Most poignantly he says, “'You don't see yourself very clearly, you know... Trust me just this once - you are the opposite of ordinary"' (Meyer 210). Edward directly contradicts the image that Bella has created for herself within the first half of the novel. This quote follows a rant in which Bella insists she is "practically disabled" and "ordinary," yet here her romantic interest insists the opposite. This is also the first challenge of her own self perception within the novel, offered by the theoretically trustworthy Edward. 
He also compares her to a drug addiction, claiming that she is his "own personal brand of heroin" (Meyer 268). This analogy enhances the level of desire that Edward expresses towards Bella. The inclusion of his desire towards her is important to her self-image. While she creates an image of an ordinary, mature yet childish girl, Edward continually assures her that she is much more than that, and even further, that he is addicted. By including it within her own narration, it shows the importance of his desire to Bella. His attraction to her, both her personality and her blood, are valued within the novel because of their inclusion. Bella frequently talks about his perfection, but what is notable is the inclusion of how others view her as desirable. He, as this theoretically perfect person proposed by Bella, claims that she is also a feat of desirability. At the same time, he is also claiming her as "his" with this sentiment. By aligning her scent to something made for him, he is then claiming her as his own. This sort of claiming upholds patriarchal standards by placing his needs and importance over hers. Even more so when considering the dangers of his temptation towards her.

Within this description of Edward and the parts of the relationship that Bella chooses to show and acknowledge, she also chooses to highlight aspects of gaslighting, or psychological manipulation that Edward uses to undermine her. Even when he is acknowledging how she is viewed as perfect to him, he states, "'You don't see yourself very clearly"” (Meyer 210). By including this interaction, Bella acknowledges their relationship hinges on him correcting her own assumptions and perceptions of herself. Rather than a gradual change of perceptions over time, Bella's own view of herself is contradicted and challenged by Edward, which in turn changes her own perceptions. Her own image of herself, and the way that she views herself, is consistently altered by Edward's insistence that she cannot perceive reality correctly. 
He challenges her from the beginning, starting with the car accident that he prevents. $\mathrm{He}$ says, “'You hit your head, you don't know what you're talking about”" (Meyer 64). This undermining of her own beliefs that he had crossed the parking lot quickly in order to save her are undermined by his insistence that she was misremembering the entire scenario. By doing this to her, she inevitably doubts herself. Despite her original assertion that she had perceived the entire event correctly, she says, "I could hear how crazy it sounded" (Meyer 64). Through his manipulation and insistence that she could not perceive things, she has a slip in her resolve and doubts herself. Even as he doubts her, she has the ability to believe in herself, moving forward with a distinct resolve that her own perception of events is the truth.

This example not only shows the ways in which Edward manipulates her and challenges her own perceptions and abilities, but the way in which Bella reacts as a result. She has a moment of self doubt, but also inevitably doubles down on her own perceptions. She includes her own strength within the novel, and in particular when faced with Edward. Her strength as a person is what builds her character as a reliable narrator and a relatable character; she offers imperfections of herself while still being confident and having a resound sense of self. Others frequently view her the way that she views herself; she is a reliable person with accurate perceptions of her world, even frequently more perceptive than her peers. It is often only when Edward makes alternate claims that her view as a truthful and perceptive person is challenged. His own viewpoint of her, degrades her as a woman, and as a freethinking person. By challenging her own perception of reality, he is making the greater statement that she is not capable of perceiving the world as a whole.

\section{Conclusion}


The novel itself presents characters in relatively traditional ways. While Bella deviates from some specific feminine ideals, like wearing makeup or dressing feminine, she still continues to uphold traditional gender roles. Beyond liking housewife work and upholding caretaker roles, she also praises others within the novel for doing the same. By emphasizing the differences between her own mother and Esme - the perfect mother- Bella is making a larger statement about the importance of motherhood and housewife ideals. To continue that, Bella also favors traditionally attractive characteristics that are present within the vampires, while shunning those around her for deviating from those same ideals. Her own perceptions of gender allude to a stricter definition of what it means to be a male or female.

The definition of feminism that I am working with firmly states the necessity of empowerment and equality. In large, Bella embodies aspects of the "choice" argument that some feminists rely on, and that Meyer heralds. The concept of choice alone does not make her a feminist character, as some scholars would argue. The choices that she makes do nothing to prove that she is working from a feminist perspective and instead push her further towards a specific anti-feminist belief. Rather than choosing to break away from stereotypes, as one would expect with the idyllic concept of "choice" feminism, she instead continues to uphold traditional beliefs about herself and puts others down for not adhering to her own concepts of gender representation.

Bella's character, narration, and overall perceptions of others do not support an argument that she is a feminist character. She frequently puts others down, including herself, while praising and upholding traditional patriarchal gender roles. She not only does this with her peers and classmates, by comparing the human boys to the "perfect" Edward, but she does this with her own parents. Her own feelings about her parents are tainted with the fact that she views other 
parents, and particularly Esme and Carlisle Cullen, as more apt and fulfilling their traditional maternal and patronal roles better. She willingly places herself out of power with Edward, whose vampire status allows the patriarchal power system to function between the two of them. Beyond creating an unbalanced power relationship between herself and Edward, she continues to pursue the danger despite several warnings from him. Edward famously says, “'What if I'm not the superhero? What if I'm the bad guy?"' (Meyer 92). Despite his warning, she chooses to ignore him in favor of continually putting herself out of power and subjecting herself to him however possible. By continually putting herself in a subservient position, not only with Edward but with her father and friends, she is acting in accordance with anti-feminist beliefs.

According to the Rebecca Walker's definition of feminism, Bella is firmly not a feminist. She does absolutely nothing to create an equality for herself with her peers, and she certainly does not allow others around her to escape her judgements and perceptions of their own roles in society. She uses her perceptions to make snap judgements and often degrades people because of this. By specifically degrading herself, other female characters, and even her male peers, she is not allowing any sense of equality. On top of that, she raises the vampires in the novel far above everyone else, proving quickly that there is no possible way to achieve equality. She does not empower herself or others, and the internalized patriarchal beliefs that she has express themselves in specifically anti-feminist ways. Her own perceptions, thoughts, and judgements are steeped in traditional gender roles and anti-feminist thought.

1. For more see Goebel. 


\section{Works Cited}

Bealer, Tracy L. "Of Monsters and Men: Toxic Masculinity and the Twenty-First Century Vampire in the Twilight Saga." Bringing Light to Twilight: Perspectives on a Pop Culture Phenomenon, by Giselle Lisa Anatol, Palgrave Macmillan US, New York, NY, 2011, pp. 139-151.

Cochrane, Kira. "Stephenie Meyer on Twilight, Feminism and True Love." The Guardian, www.theguardian.com/books/2013/mar/11/stephenie-meyer-twilight-the-host.

Collins, Victoria E, and Dianne C Carmody. "Deadly Love: Images of Dating Violence in the ‘Twilight Saga."' Journal of Women and Social Work, vol. 26, no. 4, 2011, pp. 382-394.

Dietz, Tammy. "Wake Up, Bella! A Personal Essay on Twilight, Mormonism, Feminism, and Happiness." Bringing Light to Twilight: Perspectives on a Pop Culture Phenomenon, by Giselle Lisa Anatol, Palgrave Macmillan US, New York, NY, 2011, pp. 99-111.

“Feminism.” Merriam-Webster, Merriam-Webster, 2017, www.merriamwebster.com/dictionary/feminism.

Flynn, Meghanne, and Sarah Hardstaff. “'Trust Me': Volatile Markets in Twilight and The Hunger Games.” CR: The New Centennial Review, vol. 19, no. 1, 2019, pp. 205-228.

Gerhards, Lea. "The Legacy of Lucy Westenra: Female Postfeminist Subjects in The Vampire Diaries, True Blood and The Twilight Saga." Rethinking Gender in Popular Culture in the 21st Century: Marlboro Men and California Gurls, edited by Astrid M. Fellner et al., Cambridge Scholars, 2017, pp. 89-110.

Goebel, Michael J. “'Embraced' by Consumption: Twilight and the Modern Construction of Gender." Bringing the Light to Twilight: Perspectives on the Pop Culture Phenomenon, Palgrave Macmillan , 2011, pp. 169-178. 
Howe, Jenny L. “'I Can’t Always Be Lois Lane... I Want To Be Superman Too’: Twilight, Gender Studies and Encouraging Analysis in the College Composition Classroom.” Young Adult Literature in the Composition Classroom: Essays on Practical Applications, edited by Tamara Girardi and Abigail G. Scheg, McFarland \& Company Publishing, 2018, pp. 156-168.

Jarvis, Christine. "The Twilight of Feminism? Stephenie Meyer's Saga and the Contradictions of Contemporary Girlhood." Children's Literature in Education: An International Quarterly, vol. 45, no. 2, June 2014, pp. 101-115.

Mangan, Lucy. "Dangerous liaisons." The Guardian 4 (2008).

McFarland, Jami. "Resuscitating the Undead Queer in Stephanie Meyer's Twilight Saga." Journal of Popular Romance Studies, vol. 5, no. 2, July 2016, pp. 1-22.

Meyer, Stephenie. "Frequently Asked Questions: Breaking Dawn.” Stephenie Meyer, 19 July 2016, stepheniemeyer.com/the-books/breaking-dawn/frequently-asked-questionsbreaking-dawn/.

Nichol, Rhonda. “'When You Kiss Me, I Want to Die': Arrested Feminism in Buffy the Vampire Slayer and the Twilight Series." Bringing Light to Twilight: Perspectives on a Pop Culture Phenomenon, by Giselle Lisa Anatol, Palgrave Macmillan US, New York, NY, 2011, pp. 113-121.

Parke, Maggie, and Natalie Wilson. Theorizing Twilight: Critical Essays on What's at Stake in a Post-Vampire World. McFarland \& Co., 2011.

---. "Denial and Salvation: The Twilight Saga and Heteronormative Patriarchy." Theorizing Twilight: Critical Essays on What's at Stake in a Post-Vampire World, by Ashely Donnelly, McFarland \& Co., Jefferson, 2011, pp. 178-193. 
Petersen, Anne Helen. “That Teenage Feeling.” Feminist Media Studies, vol. 12, no. 1, 11 Apr. 2011, pp. 51-67.

Perez, Lexy. “'Twilight' Companion Novel 'Midnight Sun' Sells 1M Copies in First Week of Publication." The Hollywood Reporter, 13 Aug. 2020, www.hollywood reporter.com/news/twilight-companion-novel-midnight-sun-sells-1 mcopies-first-week-publication-1307389.

Priest, Hannah. "Sparkly Vampires and Shimmering Aliens: The Paranormal Romance of Stephenie Meyer." Twenty-First-Century Popular Fiction, edited by Bernice M. Murphy and Stephen Matterson, Edinburgh University Press, 2018, pp. 182-192.

Rocha, Lauren. "Wife, Mother, Vampire: The Female Role in the Twilight Series." Journal of International Women's Studies, vol. 15, no. 2, July 2014, pp. 286-298.

Ryan, Mary. "Once Bitten: Patriarchy and Feminism in the Twilight Saga." Beyond the Night: Creatures of Life, Death, and In-Between, Cambridge Scholars, 2015, pp. 136-157. Rubinstein-Avila, Eliane. "Examining Representations of Young Adult Female Protagonists through Critical Race Feminism.” Changing English, vol. 14, no. 3, 27 Nov. 2007, pp. 363-374.

Snyder-Hall, R. Claire. "Third-Wave Feminism and the Defense of 'Choice."” Perspectives on Politics, vol. 8, no. 1, 2010, pp. 255-261. JSTOR, www.jstor.org/stable/25698533. Accessed 18 Aug. 2020.

Taylor, Jessica. "Romance and the Female Gaze Obscuring Gendered Violence in The Twilight Saga." Feminist Media Studies, vol. 14, no. 3, 11 Dec. 2012, pp. 388-402.

Walker, R. (2001). Becoming the Third Wave. In 1123304521847739467 B. Ryan (Author), Identity Politics in the Women's Movement (pp. 78-80). New York University Press. 
Whitton, Merinne. “'One Is Not Born a Vampire, but Becomes One': Motherhood and Masochism in Twilight." Bringing Light to Twilight: Perspectives on a Pop Culture Phenomenon, by Giselle Lisa Antol, Palgrave Macmillan US, New York, NY, 2011, pp. $125-135$.

Wilson, Natalie. “Got Vampire Privilege?” Seduced by Twilight: the Allure and Contradictory Messages of the Popular Saga, by Natalie Wilson, McFarland \& Co., Jefferson, 2011, pp. $157-179$.

---. "Sexually Eclipsed." Seduced by Twilight: the Allure and Contradictory Messages of the Popular Saga, by Natalie Wilson, McFarland \& Co., Jefferson, 2011, pp. 106-132. ---. "Vamping Femininity." Seduced by Twilight: the Allure and Contradictory Messages of the Popular Saga, by Natalie Wilson, McFarland \& Co., Jefferson, 2011, pp. 61-82.

Younger, Beth. "Pleasure, Pain, and the Power of Being Thin: Female Sexuality in Young Adult Literature.” NWSA Journal, vol. 15, no. 2, 2003, pp. 45-56. JSTOR. 